DOI 10. 18307/2016. 0311

(C) 2016 by Journal of Lake Sciences

\title{
黑龙江扎龙湿地不同功能区浮游植物群落与环境因子的关系
}

\author{
张因因 ${ }^{1}$, 刘宜釒 $^{2}$, 藏淑英 ${ }^{1 * *}$ \\ (1: 哈尔滨师范大学现代实验中心, 哈尔滨 150025) \\ (2: 哈尔滨医科大学基础医学学院,哈尔滨 150081)
}

\begin{abstract}
摘 要: 为研究黑龙江扎龙湿地不同功能区浮游植物群落结构分布及其与环境因子的关系, 于 2010 年 7-8 月在扎龙湿 地 4 个功能区 340 个研究点进行水环境样品采集分析. 样品共鉴定出浮游植物 6 门 80 属 354 种, 各门类细胞密度变化范 围为 $0.06 \times 10^{6} \sim 37.82 \times 10^{6}$ cells $/ \mathrm{L}$. 主要优势种为普通小球藻 (Chlorella vulgaris)、梅尼小环藻 (Cyclotella meneghiniana)、 旋转囊裸藻 (Trachelomonas volvocina) 等. 各功能区浮游植物优势种差异较大, 核心区中放射舟形藻 ( Navicula radiosa)、弯 棒杆藻 (Rhopalodia gibba) 、扁圆卵形藻 (Cocconeis placentula) 等为优势种类, 而排污区中梅尼小环藻、普通小球藻、巨颤藻 (Oscillatoria princes)、固氮鱼腥藻 (Anabaena azotica) 等处于优势地位. 主成分分析表明在扎龙湿地水环境中浊度和总磷浓 度是影响浮游植物生长的主要因素, 典范对应分析结果表明总氮浓度、总磷浓度、电导率、浊度对浮游植物属种分布影响 较大, 梅尼小环藻、箱形桥弯藻 (Cymbella cistula) 、美丽星杆藻 (Asterionella formosa) 、普通小球藻、旋转囊裸藻等受环境因 子的影响较为明显.
\end{abstract}

关键词: 浮游植物群落; 环境因子;典范对应分析; 扎龙湿地

\section{Relationships between phytoplankton community in different functional regions and envi- ronmental factors in Zhalong Wetland, Heilongjiang Province}

\author{
ZHANG Nannan $^{1}$, LIU Yixin ${ }^{2} \&$ ZANG Shuying ${ }^{1 * *}$ \\ (1: Modern Laboratory Centre, Harbin Normal University, Harbin 150025, P.R.China) \\ (2: Basic Medical Sciences, Harbin Medical University, Harbin 150081, P.R.China)
}

\begin{abstract}
Samples were carried out at 340 sites of four functional areas in Zhalong Wetland during July and August 2010 in order to study the structure of phytoplankton community and its relationship with environment factors. Totally 6 phylum, 80 genera and 354 species of phytoplankton were identified. The phytoplankton abundance ranged from $0.06 \times 10^{6}$ to $37.82 \times 10^{6}$ cells/L. The dominant species were Chlorella vulgaris, Cyclotella meneghiniana and Trachelomonas volvocina. The phytoplankton community structures in different functional regions were different. In the core region, the dominant species were Navicula radiosa, Cocconeis placentula and Rhopalodia gibba, while Oscillatoria princes and Anabaena azotica were dominant species in the discharge region. Principal components analysis indicated that turbidity and total phosphorus in the water environment were main factors effecting the growth of phytoplankton in Zhalong Wetland. Canonical correspondence analysis illuminated total nitrogen, total phosphorus, turbidity and conductivity could be the main forces structuring on the phytoplankton community in Zhalong Wetland. Cymbella cistula, Asterionella formosa, Chlorella vulgaris and Trachelomonas volvocina were affected greatly by physicochemical factors.
\end{abstract}

Keywords: Phytoplankton community; environment factors; canonical correspondence analysis; Zhalong Wetland

浮游植物是湿地生态系统中的重要组成部分、食物链的基础环节、水环境有机物的生产者, 其组成和多 样性的变化将直接影响到湿地生态系统的结构与功能 ${ }^{[1-2]}$, 对湿地生态系统平衡的维持起到至关重要的作

* 国家青年科学基金项目 (41401589)、黑龙江省自然科学基金项目 (ZD201308) 和哈尔滨师范大学博士科研启动基 金项目 (XKB201313) 联合资助. 2015-07-01 收稿;2015-08-04 收修改稿. 张因因 (1982 ), 女, 博士; E-mail: nannan04141314@163. com.

** 通信作者;E-mail: zsy6311@163.com. 
用. 浮游植物的种类组成、生物量等群落特征是评价水环境质量的重要指标, 其种类组成和结构的变化具有 一定的规律, 主要受相关的物理、化学和生物等环境因子的影响 ${ }^{[3-4]}$. 浮游植物与环境因子之间有着十分密 切的关系,其种类的组成和分布对环境因子的变化具有指示作用,同时环境条件的改变也直接或间接地影 响到浮游植物的群落结构 ${ }^{[5-7]}$.

扎龙湿地位于我国黑龙江省的西部 $\left(46^{\circ} 52^{\prime} \sim 47^{\circ} 32^{\prime} \mathrm{N}, 123^{\circ} 47^{\prime} \sim 124^{\circ} 37^{\prime} \mathrm{E}\right)$, 总面积 $2100 \mathrm{~km}^{2}$, 以小型浅 水湖泊、草甸及广阔的芦苇沼泽为主要特征, 是我国北方同纬度地区保留最原始、最完善、最广阔的湿地生 态系统 ${ }^{[8]}$. 按照有关规定, 并结合保护区珍稀水禽及湿地资源状况, 将湿地划分为核心区、缓冲区和实验区. 核心区面积为 $700 \mathrm{~km}^{2}$, 为保存完好的典型湿地生境, $80 \%$ 以上为芦苇沼泽, 是鹤类等珍稀水禽重要的栖息 地和巢区分布地; 缓冲区面积为 $670 \mathrm{~km}^{2}$, 分布着成片或断续的芦苇沼泽、苔草及湖泡, 也是鹤类等珍稀水禽 的活动领域, 但区内村屯较多, 有铁路、公路干线和大型水利工程; 实验区面积为 $730 \mathrm{~km}^{2}$, 生境与缓冲区相 似,但有开放生态旅游 ${ }^{[9]}$; 而通过实地调查发现林甸县的生活和工业污水排人湿地的流经区域设定为排污 区,该区受人为活动的影响较大, 保护区的沟渠和蔓延的湿地虽然有芦苇、苔草分布, 但有的水表面呈现黑 色、底部为黑色淤泥. 近十几年来, 随着区域气候变化及人类活动的剧烈影响, 扎龙湿地的水文格局已经发 生了深刻变化 ${ }^{[10]}$, 沼泽湿地面积日渐减小、湿地水质局部恶化、生态功能下降、生物多样性受到威胁 ${ }^{[11]}$. 对 扎龙湿地浮游植物的研究主要集中在浮游植物种类组成、群落结构特征、水质评价等方面 ${ }^{[12-13]}$, 而浮游植物 群落结构与环境因子之间关系的研究较少. 因此本文选取扎龙湿地为研究对象, 从不同功能区浮游植物种 类组成、群落结构同环境因子之间的关系等几个方面人手,将生物指标、环境指标同 ArcGIS 软件结合,研究 湖泊浮游植物在不同功能区的空间变化特征, 分析扎龙湿地湖泊水体环境的变化趋势. 采用主成分分析方 法解析不同功能区主要的污染源, 典范对应分析将浮游植物种类与环境因子相结合, 探讨环境因子与浮游 植物之间的关系,从而为扎龙湿地水环境保护提供科学依据.

\section{1 材料与方法}

\section{1 采样点设置}

扎龙自然保护区位于黑龙江省西部, 齐齐哈尔市南部, 是双阳河流至下游、嫩江支流乌裕尔河失去明显 河道, 河水漫溢形成的大面积永久性和季节性淡水沼泽地. 地处中温带, 属大陆季风气候, 全年平均气温 $3.5^{\circ} \mathrm{C}$, 年均降水量 $420 \mathrm{~mm}^{[14-15]}$. 参照《湖泊生态调查观测与分析》 ${ }^{[16]}$ 进行采样点的设置, 利用 GPS 进行精 确定位, 根据各功能区生态特征不同, 共设置 340 个采样点, 其中核心区 126 个采样点, 缓冲区 104 个采样 点, 实验区 63 个采样点, 排污区 47 个采样点, 具体采样点分布如图 1 .

\section{2 样品采集与分析}

对扎龙湿地水环境进行采样, 现场用 Manta 2 多参数水质监测仪测定水体的 $\mathrm{pH}$ 值、电导率 (SpCond)、 浊度 (Turb)、叶绿素 a (Chl.a) 浓度等水质指标. 水样采集后冷藏保存, 带回实验室的水样用于测定高锰酸盐 指数 $\left(\mathrm{COD}_{\mathrm{Mn}}\right)$ 、总氮 $(\mathrm{TN})$ 和总磷 $(\mathrm{TP})$ 浓度等, 其方法参照 《水和废水监测分析方法 $\rangle^{[17]}$.

用 $25^{\#}$ 浮游生物网, 在采样点水中沿“ $\infty$ ” 字形进行缓慢拖拉采集定性浮游植物样品, 带回实验室后镜 检、鉴定; 用 $2.5 \mathrm{~L}$ 有机玻璃采样器采集定量浮游植物样品, 定容至 $1 \mathrm{~L}$, 沉淀 $24 \sim 48 \mathrm{~h}$, 采用虹吸法慢慢吸去 上清液, 直到浮游植物浓缩到 $30 \mathrm{ml}$. 取浓缩液 $0.1 \mathrm{ml}$ 置于浮游植物生物计数框, 显微镜 ( $40 \times$ 或 $100 \times$ 油镜) 下观察、鉴定 (硅藻鉴定前需经酸处理)、计数 ${ }^{[18-21]}$.

\section{3 数据分析}

1.3. 物种多样性分析 采用 Margalef 丰富度指数 $(D)$ 、Shannon-Wiener 多样性指数 $\left(H^{\prime}\right)$ 及优势度描述群落 内种类多样性和优势种 ${ }^{[22-23]}$, 计算公式分别为:

$$
\begin{gathered}
H^{\prime}=-\sum_{i=1}^{S}\left(\frac{n_{i}}{N} \cdot \ln \frac{n_{i}}{N}\right) \\
D=\frac{S-1}{\ln N} \\
Y=\frac{n_{i}}{N} \cdot f_{i}
\end{gathered}
$$


式中, $S$ 为浮游植物种数; $N$ 为浮游植物个体总数; $n_{i}$ 为第 $i$ 种浮游植物的个体数; $f_{i}$ 为第 $i$ 种浮游植物在各采 样点出现的频率; $Y$ 为优势度, 并将 $Y>0.02$ 的物种作为优势种.

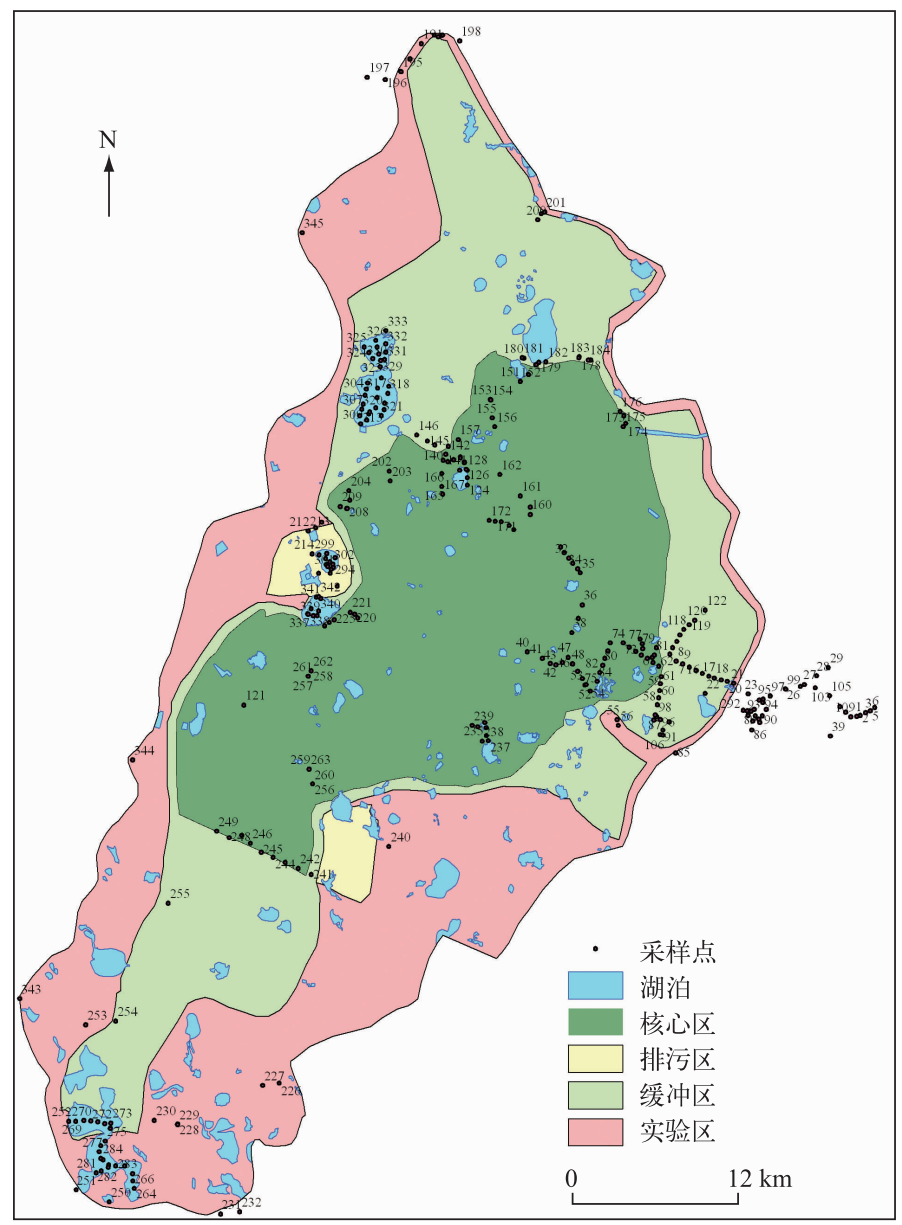

图 1 扎龙湿地保护区采样点分布

Fig.1 Distribution of sampling sites in Zhalong Wetland

1.3.2 典范对应分析 典范对应分析 (Canonical Correspondence Analysis, CCA) 是一种非线性多元梯度分析 方法, 可以有效地研究物种分布与环境的关系 ${ }^{[24]}$. 对浮游植物数据和环境数据进行排序分析, 浮游植物至 少在一个样点的相对丰度 $>1 \%$, 物种矩阵经过 $\lg (x+1)$ 转换, 水环境因子数据除 $\mathrm{pH}$ 值外, 数据分析前进行 $\lg (x+1)$ 转换使数据符合正态分布. 手动选择若干个影响显著 $(P<0.05$ 且与其他显著变量间的膨胀因子 $<$ $10)$ 的因子进行分析 ${ }^{[25-26]}$.

主成分分析和典范对应分析采用 CANOCO 4.5 完成. 各种统计学检验使用 SPSS 16.0 软件完成, 采样点 分布作图采用 ArcGIS 9.3 软件完成.

\section{2 结果与分析}

\section{1 不同功能区浮游植物群落结构特征}

2. 1.1 浮游植物群落组成 对扎龙湿地浮游植物进行调查, 共鉴定出浮游植物 354 种, 隶属于 6 门 8 纲 21

目 33 科 80 属, 其中, 绿藻门 11 科 36 属 150 种, 硅藻门 10 科 24 属 116 种, 蓝藻门 6 科 11 属 45 种, 裸藻门 2 科 5 属 39 种, 甲藻门 3 科 3 属 3 种, 金藻门 1 科 1 属 1 种 (图 2). 


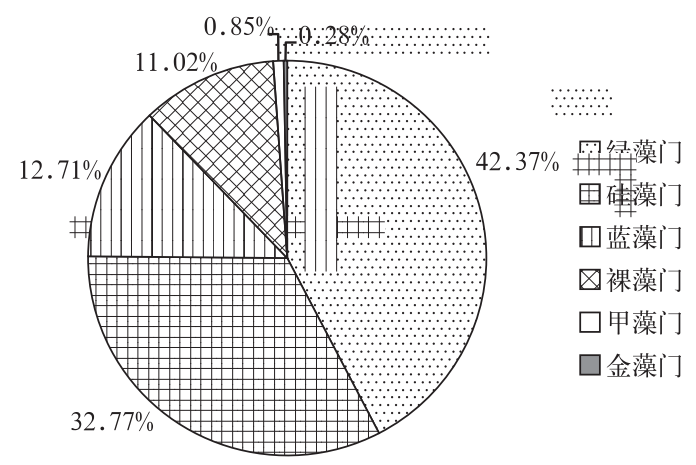

图 2 扎龙湿地浮游植物群落门类构成

Fig.2 The composition of phytoplankton community in Zhalong Wetland

扎龙湿地各功能区的浮游植物群落结构存在差异. 核心区共发现浮游植物 222 种,隶属于 6 门 66 属; 缓 冲区共发现浮游植物 210 种, 隶属于 6 门 63 属; 实验区共发现浮游植物 167 种, 隶属于 6 门 63 属; 排污区共 发现浮游植物 111 种,隶属于 6 门 47 属(表 1 ).

表 1 扎龙湿地各功能区浮游植物群落结构组成

Tab.1 The composition of phytoplankton community in different regions of Zhalong Wetland

\begin{tabular}{|c|c|c|c|c|c|c|}
\hline 功能区 & 门 & 纲 & 目 & 科 & 属 & 种 \\
\hline \multirow[t]{6}{*}{ 核心区 } & 硅藻门 & 2 & 6 & 10 & 20 & 69 \\
\hline & 绿藻门 & 2 & 6 & 11 & 33 & 98 \\
\hline & 蓝藻门 & 1 & 3 & 5 & 7 & 34 \\
\hline & 裸藻门 & 1 & 1 & 1 & 4 & 19 \\
\hline & 金藻门 & 1 & 1 & 1 & 1 & 1 \\
\hline & 甲藻门 & 1 & 1 & 1 & 1 & 1 \\
\hline \multirow[t]{6}{*}{ 缓冲区 } & 绿藻门 & 2 & 7 & 11 & 31 & 86 \\
\hline & 硅藻门 & 2 & 6 & 10 & 19 & 75 \\
\hline & 蓝藻门 & 1 & 3 & 5 & 9 & 23 \\
\hline & 甲藻门 & 1 & 1 & 2 & 2 & 2 \\
\hline & 金藻门 & 1 & 1 & 1 & 1 & 1 \\
\hline & 裸藻门 & 1 & 1 & 1 & 4 & 23 \\
\hline \multirow[t]{6}{*}{ 实验区 } & 绿藻门 & 2 & 4 & 10 & 25 & 76 \\
\hline & 硅藻门 & 2 & 6 & 10 & 19 & 47 \\
\hline & 蓝藻门 & 1 & 3 & 5 & 8 & 21 \\
\hline & 甲藻门 & 1 & 1 & 3 & 3 & 3 \\
\hline & 金藻门 & 1 & 1 & 1 & 1 & 1 \\
\hline & 裸藻门 & 1 & 1 & 2 & 5 & 19 \\
\hline \multirow[t]{6}{*}{ 排污区 } & 绿藻门 & 2 & 5 & 11 & 20 & 42 \\
\hline & 硅藻门 & 2 & 4 & 6 & 12 & 36 \\
\hline & 蓝藻门 & 1 & 3 & 5 & 8 & 18 \\
\hline & 甲藻门 & 1 & 1 & 1 & 1 & 1 \\
\hline & 金藻门 & 1 & 1 & 1 & 1 & 1 \\
\hline & 裸藻门 & 1 & 1 & 1 & 5 & 13 \\
\hline
\end{tabular}

2.1 .2 浮游植物细胞密度 扎龙湿地各功能区浮游植物各门类平均细胞密度为 $12.71 \times 10^{6}$ cells $/ \mathrm{L}$. 硅藻门 
细胞密度最大, 为 $37.82 \times 10^{6}$ cells $/ \mathrm{L}$ ( 占浮游植物细胞密度的 $49.6 \%$ ) ; 绿藻门次之, 为 $19.98 \times 10^{6}$ cells $/ \mathrm{L}($ 占 浮游植物细胞密度的 $26.2 \%$ ); 蓝藻门位居第 3 , 为 $11.43 \times 10^{6} \mathrm{cells} / \mathrm{L}($ 占浮游植物细胞密度的 $15.0 \%$ ); 其次 依次为裸藻门、甲藻门和金藻门, 细胞密度分别为 $4.96 \times 10^{6} 、 1.95 \times 10^{6}$ 和 $0.06 \times 10^{6}$ cells $/ \mathrm{L}$ ( 分别占浮游植物 细胞密度的 $6.5 \% 、 2.56 \%$ 和 $0.08 \%$ ). 扎龙湿地浮游植物主要的优势种包括放射舟形藻 (Navicula radiosa Kützing)、梅尼小环藻 (Cyclotella meneghiniana Kützing)、普通小球藻 (Chlorella vulgaris Beijerinck)、旋转囊裸 藻 ( Trachelomonas volvocina Her.) 等.

扎龙湿地 4 个功能区的浮游植物各门类细胞密度存在一定差异 (图 3). 扎龙湿地核心区浮游植物平均 细胞密度为 $11.14 \times 10^{6}$ cells $/ \mathrm{L}$. 其中, 硅藻门细胞密度最大, 为 $37.36 \times 10^{6} \mathrm{cells} / \mathrm{L}$ ( 占核心区浮游植物细胞密 度的 $55.9 \%$ ) ; 绿藻门次之, 为 $15.10 \times 10^{6}$ cells/L(占核心区浮游植物细胞密度的 $22.6 \%$ ); 蓝藻门位居第 3 , 为 $11.96 \times 10^{6} \mathrm{cells} / \mathrm{L}($ 占核心区浮游植物细胞密度的 $17.9 \%$ ). 核心区浮游植物主要的优势种包括放射舟形 藻、弯棒杆藻 (Rhopalodia gibba Ehr.)、普通小球藻等(图 4).

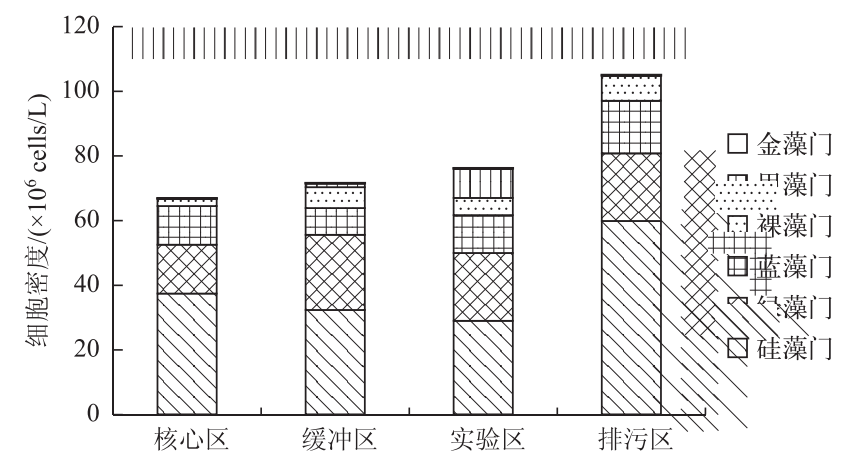

图 3 扎龙湿地各功能区浮游植物平均细胞密度

Fig.3 Phytoplankton abundance of different regions in Zhalong Wetland

扎龙湿地缓冲区浮游植物各门类平均细胞密度为 $11.92 \times 10^{6} \mathrm{cells} / \mathrm{L}$. 其中, 硅藻门细胞密度最大, 为 $32.26 \times 10^{6} \mathrm{cells} / \mathrm{L}$ ( 占缓冲区浮游植物细胞密度的 $45.1 \%$ ) ; 绿藻门次之, 为 $23.24 \times 10^{6}$ ( 占缓冲区浮游植物 细胞密度的 $32.5 \%$ ); 蓝藻门位居第 3 , 为 $8.30 \times 10^{6} \mathrm{cells} / \mathrm{L}$ (占缓冲区浮游植物细胞密度的 $11.6 \%$ ). 缓冲区 浮游植物主要的优势种包括梅尼小环藻、普通小球藻、尖布纹藻 (Gyrosigma acuminatum) 等.

扎龙湿地实验区浮游植物各门类平均细胞密度为 $12.66 \times 10^{6} \mathrm{cells} / \mathrm{L}$. 其中, 硅藻门细胞密度最大, 为 $28.94 \times 10^{6} \mathrm{cells} / \mathrm{L}$ ( 占实验区浮游植物细胞密度的 $38.1 \%$ ) ; 绿藻门次之, 为 $20.96 \times 10^{6} \mathrm{cells} / \mathrm{L}$ ( 占实验区浮 游植物细胞密度的 $27.6 \%$ ) ; 蓝藻门位居第 3 , 为 $11.70 \times 10^{6} \mathrm{cells} / \mathrm{L}$ (占实验区浮游植物细胞密度的 $15.4 \%$ ). 实验区浮游植物主要的优势种包括飞燕角甲藻 (Ceratium hirundinella)、颗粒直链藻 (Melosira granulata)、变 异直链藻 (Melosira varians) 等.

扎龙湿地排污区浮游植物各门类平均细胞密度为 $17.51 \times 10^{6}$ cells $/ \mathrm{L}$. 硅藻门细胞密度最大, 为 $59.78 \times$ $10^{6} \mathrm{cells} / \mathrm{L}$ (占排污区浮游植物细胞密度的 $56.9 \%$ ) ; 绿藻门次之, 为 $20.90 \times 10^{6} \mathrm{cells} / \mathrm{L}$ ( 占排污区浮游植物 细胞密度的 $19.9 \%$ ) ; 蓝藻门位居第 3 , 为 $16.28 \times 10^{6} \mathrm{cells} / \mathrm{L}$ (占排污区浮游植物细胞密度的 $15.5 \%$ ). 排污区 浮游植物主要的优势种包括巨颤藻 (Oscillatoria princeps)、固氮鱼腥藻 (Anabaena azotica) 、旋转囊裸藻等.

2.1 .3 扎龙湿地浮游植物多样性分析 扎龙湿地浮游植物多样性指数在排污区、实验区、缓冲区和核心区各 不相同. Margalef 丰富度指数和 Shannon-Wiener 多样性指数的最小值出现在排污区, 最大值出现在核心区. Shannon-Wiener 多样性指数在 1.26 2. 96 之间, Margalef 丰富度指数在 $0.79 \sim 3.47$ 之间 (图 5).

\section{2 扎龙湿地水环境因子的空间变化特征}

调查期间扎龙湿地 4 个功能区 340 个采样点主要理化指标空间变化如图 6. 其中 $\mathrm{pH}$ 值变化范围为 6. $25 \sim 10.11$, 平均值为 8.27. 而 SpCond 在各功能区变化较大 $(267 \sim 2456 \mu \mathrm{S} / \mathrm{cm})$, 平均值为 $764.7 \mu \mathrm{S} / \mathrm{cm}$, 在空间上从核心区到排污区逐渐递增 (平均值由 $596.9 \mu \mathrm{S} / \mathrm{cm}$ 增加到 $1561.7 \mu \mathrm{S} / \mathrm{cm}$ ). 水体中 Chl. a 浓度 

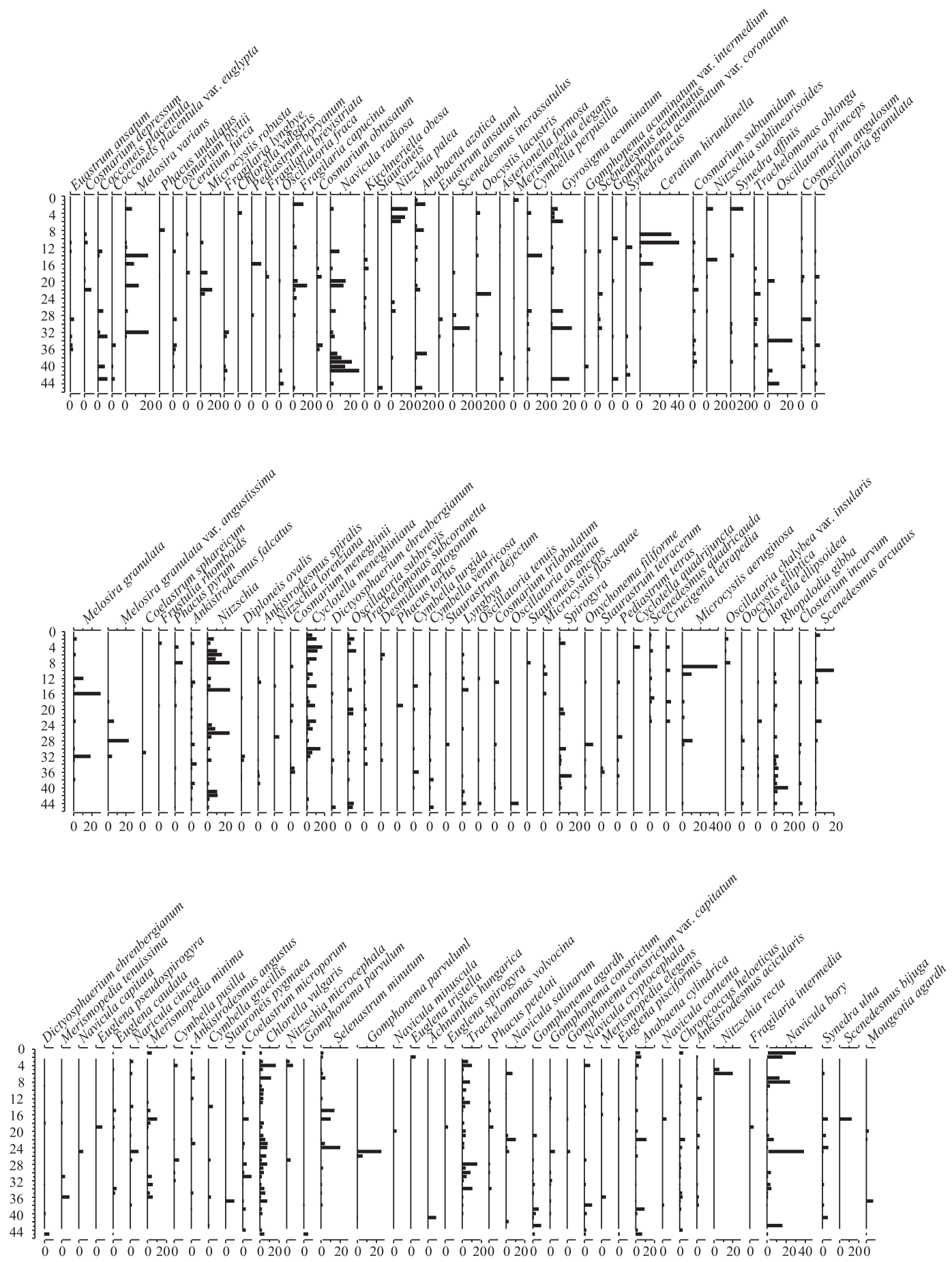

图 4 扎龙湿地浮游植物丰度组成

Fig.4 Phytoplankton abundance in Zhalong Wetland 

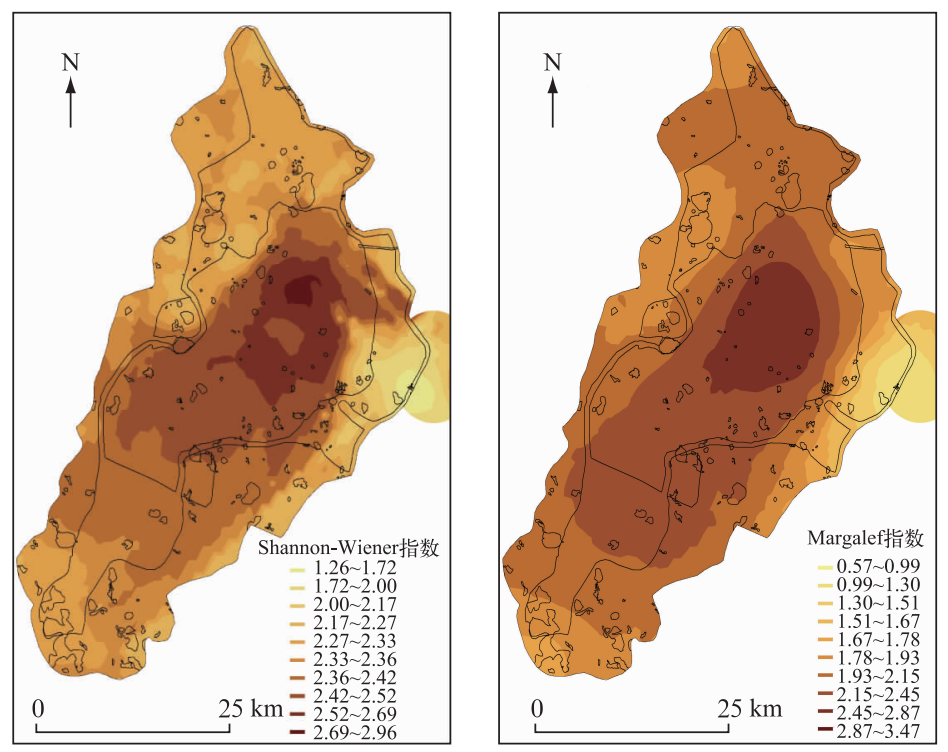

图 5 扎龙湿地浮游植物多样性指数

Fig.5 Phytoplankton diversity imdexes in Zhalong Wetland
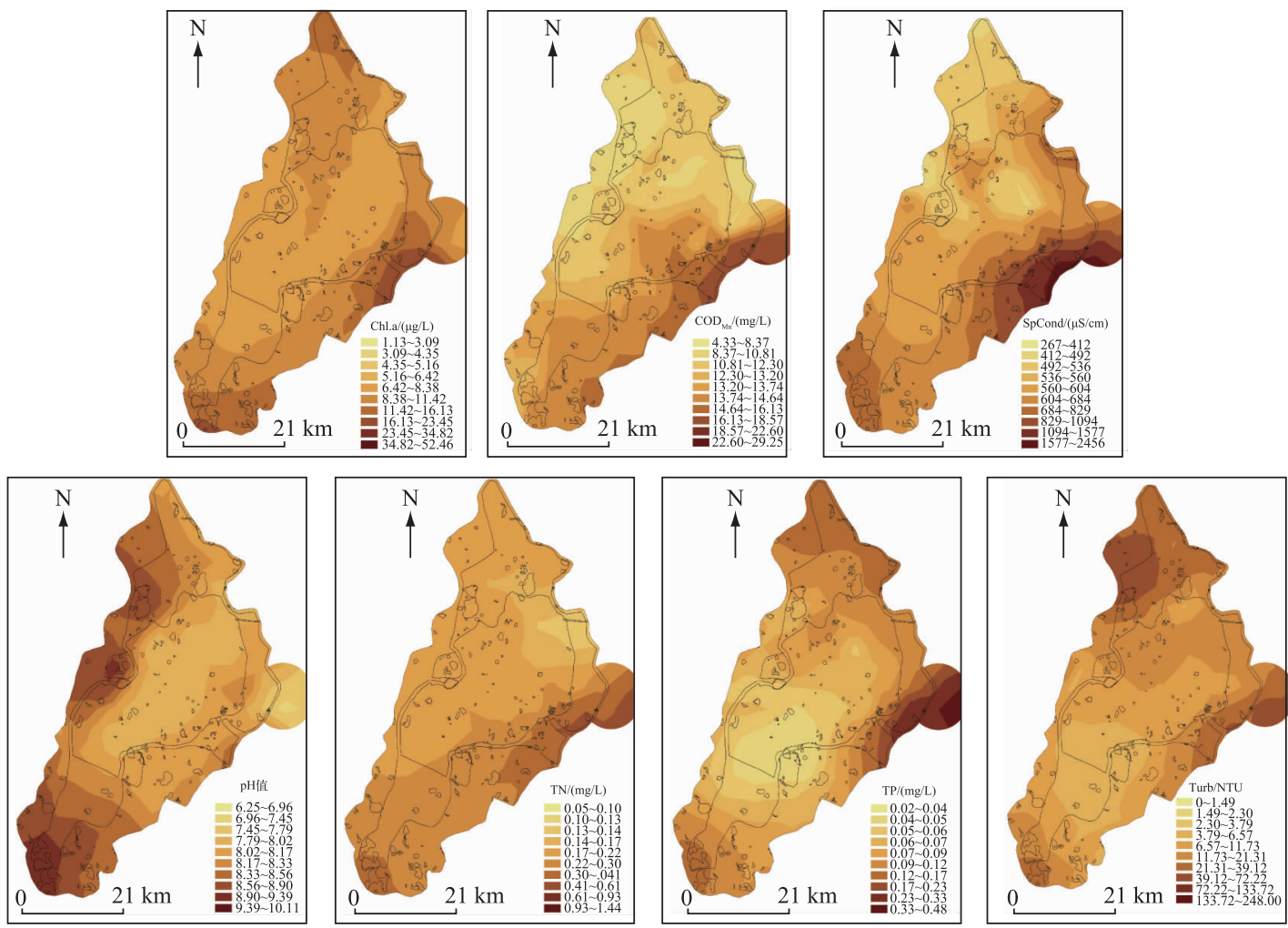

图 6 扎龙湿地水环境因子的空间分布特征

Fig.6 Spatial distribution of environmental factors in Zhalong Wetland 
(1.13 52. $46 \mu \mathrm{g} / \mathrm{L}) 、$ Turb $(0 \sim 248 \mathrm{NTU}) 、 \mathrm{TN}$ 浓度 $(0.05 \sim 1.44 \mathrm{mg} / \mathrm{L}) 、 \mathrm{TP}$ 浓度 $(0.02 \sim 0.48 \mathrm{mg} / \mathrm{L}) 、 \mathrm{COD}_{\mathrm{Mn}}$ (4. 33 29. $25 \mathrm{mg} / \mathrm{L})$ 的变化范围较大, 变化趋势较为相似, 最低值都出现在核心区, 最高值都出现在排污区. 核心区 Chl.a 浓度、pH 值、Turb、COD $\mathrm{Mn}_{\mathrm{n}}$ TN 浓度和 TP 浓度的平均值分别为 $7.57 \mu \mathrm{g} / \mathrm{L} 、 8.04 、 9.70 \mathrm{NTU}$ 、 $11.89 \mathrm{mg} / \mathrm{L} 、 0.22 \mathrm{mg} / \mathrm{L}$ 和 $0.08 \mathrm{mg} / \mathrm{L}$, 排污区的平均值分别为 $17.28 \mu \mathrm{g} / \mathrm{L} 、 7.69 、 52.34 \mathrm{NTU} 、 17.88$ $\mathrm{mg} / \mathrm{L} 、 0.46 \mathrm{mg} / \mathrm{L}$ 和 $0.30 \mathrm{mg} / \mathrm{L}$. 从环境因子的空间分布看, 在进人扎龙湿地人口处、湿地的边界地带 环境因子值相对较大, 这可能与上游工农业废水流人、边界土地开荒耕作、林甸县废水和污水排放 有关.

\section{3 浮游植物群落与环境因子的关系}

2.3.1 环境因子的主成分分析 在扎龙湿地水体研究 区中选取不同功能区的采样点, 对水体中的 Chl.a 浓 度、pH 值、SpCond Turb、 $\mathrm{COD}_{\mathrm{Mn}} 、 \mathrm{TN}$ 浓度、TP 浓度这 7 个变量进行主成分分析 ( 图 7).

PCA 分析显示第 1 轴特征值为 0.562 ,第 2 轴特征 值为 0.170 , 前 2 个排序轴对环境因子的解释量达 $73.2 \%$ (表 2), 可以表达数据的主要信息. 根据环境因 子在主成分分析的特征值, 按照每个主成分中起主要作 用的环境因子可知, $\mathrm{pH}$ 值与第 1 轴呈正相关; Chl. a 浓 度、SpCond、COD $\mathrm{Mn} 、 \mathrm{TN}$ 浓度、TP 浓度与第 2 轴呈正相 关. 从图 7 还可以看出环境变量与采样点的关系, 环境 因子较高值出现在排污区和实验区 (采样点 $1 \sim 8$ 和采 样点 9 16), 较低的理化因子值出现在缓冲区和核心区 (采样点 17 32 和采样点 $33 \sim 45$ ).

2.3. 2 浮游植物与环境因子的 CCA 分析 根据浮游植 物种类丰度和出现频率 (至少在 2 个采样点均出现且相 对丰度 $\geqslant 1 \%$ ), 选取 124 种浮游植物与环境变量进行 $\mathrm{CCA}$ 分析, 结果显示, 前两轴 TN 浓度、TP 浓度、 $\mathrm{COD}_{\mathrm{Mn}}$ 、 SpCond $、 \mathrm{pH}$ 值、Turb 和 Chl.a 浓度这 7 个环境因子对物 种数据解释率为 $50.2 \%$,第 1 轴和第 2 轴的特征值分别 为 0.464 和 0.343 , 从属种分布来看, 浮游植物绝大多数 种类都围绕在轴心周围,多数属种呈现局部小团块分 布,由中心密集向外围逐渐递减的趋势, 并与不同的环

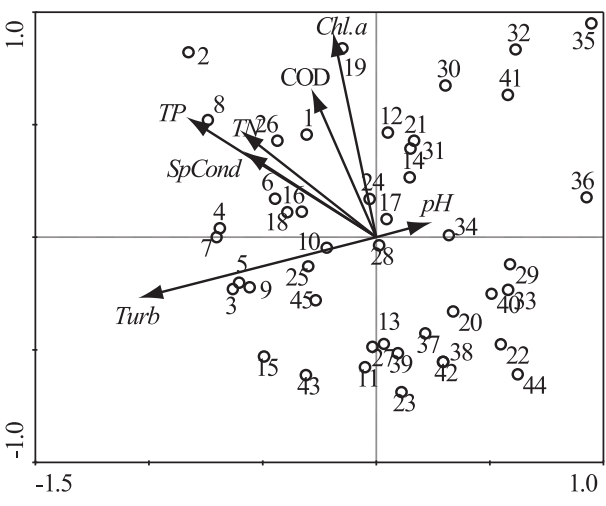

图 7 扎龙湿地采样点与环境因子的主成分分析

Fig.7 Principle component analysis of sampling sites and environmental factors in Zhalong Wetland

表 2 扎龙湿地理化因子主成分分析特征值 Tab.2 Principle component analysis of physicochemical parameters in Zhalong Wetland

\begin{tabular}{ccc}
\hline 排序轴 & 特征值 & 方差累计百分比 $/ \%$ \\
\hline 1 & 0.562 & 56.2 \\
2 & 0.170 & 73.2 \\
3 & 0.110 & 84.2 \\
4 & 0.061 & 90.4 \\
\hline
\end{tabular}
境因子紧密相关. 环境因子影响着浮游植物的属种分 布, 同时浮游植物属种的分布也受到各种环境因子的综合作用 (图 8). 通过软件自动篮选, 最后得出 TN 浓 度、TP 浓度、SpCond 和 Turb 是影响扎龙湿地群落结构的主要环境因子.

\section{3 讨论}

\section{1 扎龙湿地不同功能区浮游植物群落结构特征及其成因}

在对不同功能区调查中发现, 核心区人为影响相对较小, 浮水植物和挺水植物的覆盖度较大 ( $80 \%$ 以上 为芦苇沼泽), 水体自净能力较高, 出现月形短缝藻 (Eunotia lunaris (Ehr.) Grun.)、微星鼓藻属 (Micrasterias)、放射舟形藻等常生活在贫营养水体中的藻种. 值得一提的是, Gasse 曾报道放射舟形藻很常 见, 属普生种, 并提出这个种类常出现在中性、适度电解质的水体中 ${ }^{[27]}$, Krammer 等则报道这个种类几乎出 现在所有不同的淡水环境 ${ }^{[28]}$, 而 Langela-Bertalot 又指出该种是贫到中营养的种类, 对污水 (下水道的水) 比 较敏感 ${ }^{[19]}$, 这说明放射舟形藻的生态幅较广. 在本研究中, 尽管不同功能区水环境环境因子有所差异 (图 6), 但根据放射舟形藻分布的特点来看 (主要分布在核心区, 水环境质量较好), 可以把这个种类作为指示塞 


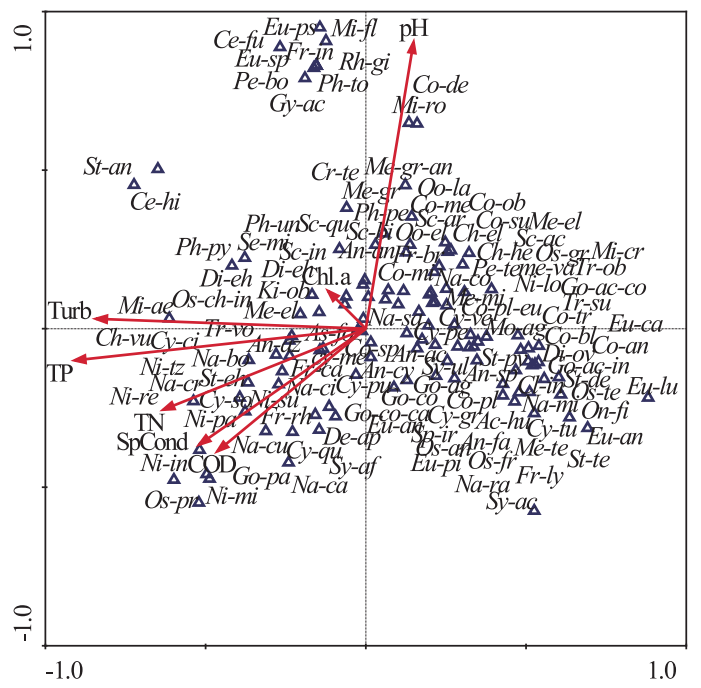

(Eu-an: Euastrum ansatum; Co-de: Cosmarium depressum; Co-pl: Cocconeis placentula; Co-pl-eu:

Cocconeis placentula var. euglypta; me-va: Melosira varians; Ph-un: Phacus undulates; Co-bl:

Cosmarium blyttii; Ce-fu: Ceratium furca; Mi-ro: Microcystis robusta; Fr-ly: Fragilaria lyngbye; Pe-bo:

Pediastrum boryanum; Fr-br: Fragilaria brevistriata; Os-fr: Oscillatoria fraca; Fr-ca: Fragilaria capucina;

Co-ob: Cosmarium obtusatum; Na-ra: Navicula radiosa; St-eh: Stauroneis Ehr.; Ni-pa: Nitzchia palea;

An-az: Anabaena azotica; Eu-an: Euastrum ansatum; Sc-in: Scenedesmus incrassatulus; Oo-la: Oocystis lacustris ;

As-fo: Asterionella formosa; Cy-pe: Cymbella perpusilla; Gy-ac: Gyrosigma acuminatum; Sc-ac:

Scenedesmus acuminatus; Go-ac-co: Gomphonema acuminatum var. coronatum; Sy-ac: Synedra acus ;

Ce-hi: Ceratium hirundinella; Co-su: Cosmarium subtumidum; Ni-su: Nitzschia sublinearisoides; Sy-af: Synedra affinis; Tr-ob: Trachelomonas oblonga; Os-pr: Oscillatoria princes; Co-an: Cosmarium angulosum; Os-gr: Oscillatoria granulate; Me-gr: Melosira granulate; Me-gr-an: Melosira granulata var. angustissima;

Co-sp: Coelastrum sphaericum; Fr-rh: Frustulia rhomboids; Ph-py: Phacus pyrum; An-fa: Ankistrodesmus

falcatus; Di-ov: Diploneis ovalis; An-sp: Ankistrodesmus spiralis; Eu-lu: Eunotion lunaris; Ni-lo:

Nitzschia lorenziana; Co-me: Cosmarium meneghinii; Cy-me: Cyclotella meneghiniana; Di-eh: Dictyosphaerium

ehrenbergianum; Os-su: Oscillatoria subbrevis; Tr-su: Trachelomonas subcoronetta; De-ap: Desmidium aptogonum; Ph-to: Phacus tortus; Cy-tu: Cymbella turgida; Cy-ve: Cymbella ventricosa; St-de: Staurastrum dejectum; Lyngbya: Lyngbya; Os-te: Oscillatoria tenuis; Co-tr: Cosmarium trilobulatum; Os-an: Oscillatoria

anguina; St-an: Stauroneis anceps; Mi-fl: Microcystis flos-aquae; On-fi: Onychonema filiforme; St-te:

Staurastrum tetracerum; Pe-te: Pediastrum tetras; Cy-qu: Cyclotella quadrijuncta; Sc-qu: Scenedesmus quadricauda; Cr-te: Crucigenia tetrapedia; Mi-ae: Microcystis aeruginosa; Os-ch-in: Oscillatoria chalybea var. insularis; Oo-el: Oocystis elliptica; Ch-el: Chlorella ellipsoidea; Rh-gi: Rhopalodia gibba; Cl-in:

Closterium incurvum; Sc-ar: Scenedesmus arcuatus; Di-eh: Dictyosphaerium ehrenbergianum; Me-te:

Merismopedia tenuissima; Na-ca: Navicula cari; Eu-ps: Euglena pseudospirogyra; Eu-ca: Euglena caudata;

Na-ci: Naricula cincta; Me-mi: Merismopedia minima; Cy-pu: Cymbella pusilla; An-an: Ankistrodesmus

angustus; Cy-gr : Cymbella gracillis; St-py: Stauroneis pygmaea; Co-mi: Coelastrum microporum; Ch-vu:

Chlorella vulgaris; Ni-mi: Nitzschia microcephala; Go-pa: Gomphonema parvulum; Se-mi: Selenastrum minutum; Na-mi: Navicula minuscula; Eu-tr: Euglena tristella; Ac-hu: Achnanthes hungarica; Eu-sp: Euglena spirogyra;

Tr-vo: Trachelomonas volvocina; Ph-pe: Phacus peteloti; Na-sa: Navicula salinarum; Go-ag: Gomphonema

Agardh; Go-co: Gomphonema constrictum; Go-co-ca: Gomphonema constrictum var. capitatum; Eu-pi :

Euglena pisciformis; An-cy: Anabaena cylindrica; Na-co: Navicula contenta; Ch-he: Chroococcus heloeticus;

An-ac: Ankistrodesmus acicularis; Ni-re: Nitzschia recta; Fr-in: Fragilaria intermedia; Na-bo: Navicula bory;

Sy-ul: Synedra ulna; Sc-bi: Scenedesmus bijuga)

图 8 扎龙湿地浮游植物属种与环境因子的典范对应分析

Fig.8 Canonical correspondence analysis between phytoplankton species and environmental factors 
污带生态环境的指示种, 并且对扎龙湿地不同功能区浮游植物群落多样性分析可知, 核心区浮游植物种类 丰富 (222 种), Margalef 丰富度指数 (2.39) 和 Shannon-Wiener 指数 (2.48) 相对较高, 说明该区水质较 好 ${ }^{[22,29-30]}$; 而在缓冲区和实验区, 浮游植物种类有所下降 (210 和 167 种), Margalef 指数 (1.75 和 1.70 ) 和 Shannon-Wiener 指数 (2.24 和 2.21) 也相对减少, 出现了梅尼小环藻、普通小球藻、飞燕角甲藻、颗粒直链藻、 旋转囊裸藻等中-富营养指示种 (图 4), 而梅尼小环藻适合生长在富营养化水环境中, 在咸水、浅水湖泊及沟 渠中常见, 可以作为中营养水体的指示种 ${ }^{[31]}$, 旋转囊裸藻为广布种, 当其大量繁殖时, 水体呈现黄褐色, 常出 现在有机质丰富的水体中 ${ }^{[32]}$, 这些浮游植物污染指示种出现可能与乌裕尔河的工业废水、生活污水及周边 水田灌区的农业污染流人扎龙湿地有关 ${ }^{[9]}$; 而在排污区, 由于林甸县的生活污水和工业废水直接排人湿地, 水质污染严重, 造成鱼类及禽鸟中毒死亡 ${ }^{[15]}$, 出现大量富营养的指示种, 如梅尼小环藻、巨颤藻、铜绿微囊藻 (Microcystis aeruginosa)、钝脆杆藻 (Fragilaria capucina) 等(图 4), 这表明水环境的污染情况与浮游植物群落 种类的变化有着密切的相关性, 并且在排污区浮游植物种类 (111 种)、Margalef 丰富度指数 (1.20) 和 Shannon-Wiener 多样性指数 (2.07) 明显降低. 在对扎龙湿地浮游植物群落结构的调查中发现, 不同功能区 中绿藻门和硅藻门都是最多的 (表 1), 这表明扎龙湿地研究区域为绿藻-硅藻型, 这与李晶等 ${ }^{[12]}$ 和于洪贤 等 ${ }^{[13]}$ 的调查结果一致, 这也与其它高纬度、高寒度地区的水体极易出现以硅藻为优势类群的浮游植物群落 特征基本一致 ${ }^{[33-34]}$.

\section{2 扎龙湿地浮游植物种类与环境因子的关系}

浮游植物的空间差异性一般除受自身生物学特性的影响外,还受到如光照、温度、营养盐等环境因子的 影响 ${ }^{[35-37]}$. 通过浮游植物与环境因子的 CCA 分析可知, TN 浓度、TP 浓度、SpCond、Turb 与第 1 排序轴呈显著 相关, 是影响扎龙湿地浮游植物属种分布的重要环境因子. $\mathrm{pH}$ 值与第 2 排序轴呈显著相关, 如尖布纹藻、梅 尼小环藻等浮游植物种类与 $\mathrm{pH}$ 值呈显著相关. 由图 8 可以明显看出, 草鞋形波缘藻 (Cymatopleura solea)、尖 头舟形藻 (Navicula cuspidate) 等与 SpCond 呈正相关, 表明这些种类受 SpCond 的影响较大, 结合浮游植物种 类丰度分析可知, 这些浮游植物多出现在水体营养盐含量较高、SpCond 较大、水环境质量较差的采样点, 说 明环境因子对浮游植物种类分布具有一定的影响.

从图 8 可以看出, TN、TP 浓度等变化将 $\mathrm{CCA}$ 第 1 轴分成两部分, 从右侧部分到左侧部分营养盐逐渐增 大, 左侧部分的浮游植物主要属于中-富营养种类, 如梅尼小环藻、普通小球藻、旋转囊裸藻、飞燕角甲藻、铜 绿微囊藻等 ${ }^{[38]}$, 结合 PCA 排序图和浮游植物丰度图分析可知, 这些中-富营养浮游植物种类大多数分布于 排污区和实验区的采样点, 而这些采样点水环境较差, 由于工、农业生产的发展和城镇人口的增加, 大量工 业污水和生活废水流人湿地, 加之地表径流内农田化肥的流失, 使得该区域营养盐和有机质大大增加, 造成 浮游植物种类减少, 细胞密度降低 ${ }^{[9,15]}$. 在受 TN、TP 浓度影响较大的左侧部分, 也出现了如梅尼小环藻、鱼 形裸藻 (Euglena pisciformis) 、颗粒直链藻、变异直链藻等浮游植物种类, 同时这些丰度较高的浮游植物种类 也是 TN、TP 浓度的指示种类 ${ }^{[38-39]}$, 该区域角甲藻、铜绿微囊藻、普通小球藻等 ${ }^{[40]}$ 多污带指示种出现的频率 较高 (图 4). 在 CCA 排序轴的右侧, 浮游植物以月形短缝藻、放射舟形藻、弯棒杆藻、小球藻等贫-中营养种 类为主, 结合 PCA 排序图分析可知, 右侧部分主要分布的采样点属于核心区, 并且一些寡污带的指示种也在

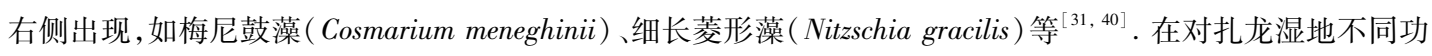
能区浮游植物群落和环境因子分析的基础上, 应用 CCA 对大量的数据进行直接梯度排序, 揭示出扎龙湿地 浮游植物种类与环境因子之间的关系. 另外按照不同功能区分析浮游植物群落结构的分布特征, 可以针对 不同功能区采取不同的保护措施, 为今后进一步合理研究扎龙湿地不同功能区的水生生物资源提供基础 资料.

\section{4 参考文献}

[ 1 ] Cardinale BJ, Palmer M, Collins S. Species diversity enhances ecosystem functioning through interspecific facilitation. $\mathrm{Na}$ ture, 2002, 415(6870) : 426-429.

[ 2 ] Polishchuk LV. Contribution analysis of disturbance-caused changes in phytoplankton diversity. Ecology, 1999, 80: 721-725.

[ 3 ] Fathi AA, Abdelzaher HMA, Flower RJ et al. Phytoplankton communities of North African wetland lakes: the CASSARI- 
NA Project. Aquatic Ecology, 2001, 35: 303-318.

[ 4 ] Teubner K. Phytoplankton, pelagic community and nutrients in a deep oligotrophic alpine lake: ratios as sensitive indicators of the use of P-resources (DRP :DOP :PP and TN :TP :SRSi). Water Research, 2003, 37: 1583-1592.

[ 5 ] Lepistö L, Holopainen AL, Vuoristo H. Type-specific and indicator taxa of phytoplankton as a quality criterion for assessing the ecological status of Finnish boreal lakes. Limnoligica, 2004, 34: 236-248.

[6] 苟 婷, 许振成, 李 杰等. 珠江流域西江支流贺江浮游藻类群落特征及水质分析. 湖泊科学, 2015, 27(3): 412-420. DOI 10. 18307/2015. 0307.

[ 7 ] 杜明勇, 于 洋, 阳 振等. 太湖流域 2012 年枯水期浮游生物群落结构特征. 湖泊科学, 2014, 26(5) : 724-734. DOI 10. 18307/2014. 0510 .

[ 8 ] 秦喜文, 张树清, 李晓峰等. 扎龙国家级自然保护区丹顶鹤巢址的空间分布格局分析. 湿地科学, 2009, 7(2): 106-111.

[ 9 ] 李兴春, 张廷坤, 赵丽华等. 扎龙湿地水资源规划-生态环境需水量专题研究报告. 长春: 松辽流域水资源保护局 水环境科学研究所, 2003 .

[10] 郭跃东, 邓 伟, 潘继花. 扎龙河滨湿地水体营养化污染特征及水环境恢复对策. 生态环境, 2003, 12(4): 393-397.

[11] Kadlec RH, Wallace S, Knight RL. Treatment Wetlands. New York/Boca Raton: Lewis Publishers, 1996.

[12] 李 晶, 祁佩时, 马 云等. 扎龙湿地夏秋季浮游植物群落结构. 东北林业大学学报, 2012, 40(5): 86-90.

[13］于洪贤, 赵 菲. 扎龙湿地浮游植物群落结构特征与水质评价. 东北林业大学学报, 2012, 40(11): 99-119.

[14] 衣伟宏, 杨 柳, 张正祥. 基于 ETM+影像的扎龙湿地遥感分类研究. 湿地科学, 2004, 2(3) : 208-212.

[15] 赵 旭. 扎龙湿地水环境与可持续发展. 湿地科学, 2005, 3(4): 286-291.

[16] 黄祥飞, 陈伟民, 蔡启铭. 湖泊生态调查观测与分析. 北京: 中国标准出版社, 1999.

[17］国家环境保护总局《水和废水监测分析方法》编委会. 水和废水监测分析方法: 第 4 版. 北京: 中国环境科学出版 社, 2002.

[18] 胡鸿钧, 魏印心. 中国淡水藻类: 系统分类及生态. 北京: 科学出版社, 2006.

[19] Langela-Bertalot H. Diatoms of the European inland waters and comparable habitats: Vol. 2. Königstein/Germany: Ruggell: ARG. Gantner Verlag KG, 2001.

[20] Krammer K. Diatoms of the European inland waters and comparable habitats:Vol. 1. Königstein/Germany: Ruggell: ARG. Gantner Verlag KG, 2000.

[21] Hustedt F. The Pennate Diatoms. USA: Koeltz Scientific Books Koeningstein, 1985.

[22］马克平. 生物群落多样性的测度方法 I $\alpha$ 多样性的测度方法(上). 生物多样性, 1994, 2(3): 162-168.

[23] 高 亚, 潘继征, 李 勇等. 江苏滆湖北部区整治后浮游植物时空分布及环境因子变化规律. 湖泊科学, 2015, 27 (4) : 649-656. DOI 10. 18307/2015. 0413.

[24] Braak CJFT. Canonical correspondence analysis: a new eigenvector technique for multivariate direct gradient analysis. Ecology, 1986, 67 ( 5$): 1167-1179$.

[25] 章宗涉, 黄群飞. 淡水浮游生物研究方法. 北京: 科学出版社, 1991.

[26] Cardoso LDS, Marques DDM. Hydrodynamics-driven plankton community in a shallow lake. Aquatic Ecology, 2009, 43 (1) : 73-84.

[27] Gasse F. East African diatoms, taxonomy, ecological distribution. Bibliotheca diatomologica, band 11. Berlin: Stuuttgart, 1986 .

[28] Krammer K, Lange-Bertalot H. Bacillariophyceae. 1. Teil: Naviculaceae, Sü wasserflora von Mitteleuropa. Gustav. Fischer Verlag, Stuttgart, Band 2-1, 1986.

[29] Proula M, Pick F, Mazumder A. Experimental evidence for interactive impacts of human activities on lake algal species richness. Oikos, 1996, 76:191-195.

[30] Watson S, Mc Cauley E, Downing J. Patterns in phytoplankton taxonomic composition across temperate lakes of differing nutrient status. Limnology and Oceanography, 1997, 42: 487-495.

[31] Krammer K, Lange-Bertalot H. Bacillariophyceae 3. Teil: Centrales, Fragilariaceae, Eunotiaceae. Berlin: SpektrumAkademischerVerlagHeidelberg, 1997.

[32] Philipose MT. Contributions to our knowledge of indian algae-ш. Euglenineae-Part- I . The genus Euglena Ehrenberg. Pro- 
ceedings of the Indian Academy of Science, 1982, 91(6) : 551-599.

[33] 李 咕, 姜作发, 马 波等. 新疆乌伦湖春、秋季浮游植物群落结构的聚类和多维分析. 中国水产科学, 2008,15 (6) : 984-991.

[34] Serra T, Colomen J, Baserba C et al. Quantified distribution of diatoms during the stratified period of Boadella reservoir. Hydrobiologia, 2002, 589: 235-244.

[35] 刘冬燕, 赵建夫, 张亚雷等. 富营养水体生物修复中浮游植物的群落特征. 水生生物学报, 2005, 29(2): 177-183.

[36] Arhonditsis GB, Winder M, Brett MT et al. Patterns and mechanisms of phytoplankton variability in Lake Washington (USA). Water Research, 2004, 38: 4013-4027.

[37] Na EH, Park SS. A hydrodynamic and water quality modeling study of spatial and temporal patterns of phytoplankton growth in a stratified lake with buoyant incoming flow. Ecological Modeling, 2006, 199: 298-314.

[38] Palmer CM. A composite rating of algae tolerating organic pollution. Journal of Phycology, 1969, 5: 78-82.

[39] Gurbuz H, Kivrak E. Use of epilithic diatoms to evaluate water quality in the Karasu River of Turkey. Environmental Biolo$g y, 2002, \mathbf{2 3}(3): 239-246$.

[40］林碧琴, 谢淑琦. 水生藻类与水体污染监测. 沈阳: 辽宁大学出版社, 1988. 